ISSN 0258-7122

Bangladesh J. Agril. Res. 40(2): 235-248, June 2015

\title{
STATUS OF CONSERVATION AGRICULTURE BASED TILLAGE TECHNOLOGY FOR CROP PRODUCTION IN BANGLADESH
}

\author{
M. ISRAIL Hossain ${ }^{1}$, M. J. U. SARKER ${ }^{2}$ AND M. ARShadUl HAQUE ${ }^{3}$
}

\begin{abstract}
Conservation agriculture (CA) based tillage technology permits direct seeding through the moderate level of crop residue. CIMMYT introduced this technology in the farmers' field of Bangladesh for wheat crop in collaboration with Wheat Research Centre, Bangladesh Agricultural Research Institute (BARI). Farmers accept CA based tillage technologies considering the advantages of higher yields, reduced cost of tillage operation, and minimum turn around time between the crops. Up land crops are more suitable under these tillage technologies. Weed management in rice cultivation is not yet in a good shape. Most of the tillage implements are operated by imported Chinese two wheel tractor (power tiller). There are few four wheel tractor CA implement using in research farm. Local manufacturers are being fabricated these cost effective small minimum tillage seed drill, raised bed planter, zero till drill, and strip till drills efficiently in different districts of Bangladesh. Farmers accept CA technologies in their field, especially raised bed planting and minimum tillage technology. There are about 425 numbers of raised bed planters and 865 minimum tillage seed drill in the country. Area coverage under bed planting and minimum tillage system are 5764 ha and 21850 ha, respectively. There are 20125 numbers of farmers involved in raised bed farming. There is a big prospect accelerating the CA based tillage technology in the farmers' field as irrigation water availability becoming limited or more costly. Mind set up is the big issue for adopting CA tillage technology. Training and multi disciplinary approaches can push forward these tillage technologies ahead.
\end{abstract}

Keywords: Conservation agriculture, zero tillage, minimum tillage, strip tillage, bed planting

\section{Introduction}

Conservation agriculture (CA) based tillage technology permits direct seeding in untilled soil with moderate level of crop residue. It is defined as the combination of three major farming principles for successful crop production with the latest technologies -less soil disturbance, crop residue management, and following beneficial crops rotation (Hobbs et al., 2008). Conservation agriculture is a winwin approach that reduces operational costs, including machinery, labour, fuel while increasing yields and better utilize natural resources (Roy et al., 2009). In

${ }^{1}$ Chief Scientific Officer (Agri. Engineer), RWRC, Bangladesh Agricultural Research Institute (BARI), ${ }^{2}$ Director, WRC, BARI, Dinajpur ; ${ }^{3}$ Senior Scientific Officer, FMPE Division, BARI, Gazipur, Bangladesh. 
greater sense, resources are time, energy, money, soil, water etc. CA aims to conserve, improve and make more efficient use of natural resources through integrated management of available soil, water and biological resources combined with external inputs. It contributes to environmental conservation as well as to enhanced and sustained agricultural production. It can also be referred to as resource efficient or resource effective agriculture (FAO web site).

Generally farmers grow rice in puddled land by manual transplanting and wheat is cultivated after $T$. aman with 3-4 numbers of ploughing and hand broadcasting seeds. This system is time consuming and costly operation. There are about $70 \%$ wheat area planted late due to lack of adoption of advanced technologies and awareness (Hossain et al., 2012). Research reports available in Bangladesh (Barma et al., 2014) revealed that wheat, maize, pulses, oilseeds, jute, rice can be established and grown successfully through CA technology. There are about 700,000 two wheel tractor (power tiller) in the country (Satter Mondal, 2013). Two wheel tractor operated CA based tillage technology has been developed by different organizations and promotional activities are being conducted in the farmer's field of Bangladesh for yield gap minimization, water saving, efficient input utilization, soil health improvement and sustainable crop production and crops diversification (Hossain et al., 2014). The Government organization, non government organizations, agricultural research institutes, donar funded agencies are trying to increase more area coverage and involve more number of farmers in CA system. CA technologies especially zero tillage and strip tillage technologies are more viable in drought stress areas where seeding operation and initial plants establishment can be done utilizing the residual soil moisture available immediate after monsoon rice harvest (Bell and Johansen, 2009). Similarly, raised bed technology with crop residue management can mitigate soil salinity some extend for better crop establishment in Southern saline problem area of Bangladesh. Machinery manufacturers are fabricating tillage implements in different locations of the country. Local machinery service providers are making business in the farmers' field as custom hire basis but the numbers of these service providers are not adequate (Hossain et al., 2014). There are huge demands of these services. Agri business started among the farming community. But, there are lacks of information related to CA implements availability, technology adoption, constraints, crop and crop production under CA system. Therefore, this study has been under taken to summarize the status of CA based tillage technology available for crops production within the country.

Objectives: The main objectives of this study are

i. to summarize the present status of conservation agriculture based tillage technologies available in Bangladesh

ii. to find out the adoption status of these technologies for crops production 


\section{Materials and Method}

The study was conducted in those areas where the CA based tillage technology of crop production was dominant such as Dinajpur, Jamalpur, Jessore, Pabna, Faridpur and Rajshahi regions. Conservation agriculture based tillage implements are available in Bangladesh and these are mostly operated by two wheel tractor imported from China. There are few imported four wheel tractor driven CA implements which are mainly used in research purposes in limited areas. There are considerable numbers of machinery manufacturers now making CA based tillage implements and spare parts in different locations of the country. The CA related information was collected from machinery manufacturers, local service providers, lead farmers, agricultural department, and machinery traders from different corners of Bangladesh. There is no established section or department with the name of conservation agriculture in the country. Personal communication was applied most of the cases for collecting the data especially number of implement, number of CA adopted farmers, area coverage.

CA implements are being used in the farmers' field of North West part, central part and Southern part of Bangladesh. Priority crops are wheat, maize and pulses. Cornell University, CIMMYT, ACIAR-SRFSI, CSISA (Cereal System Initiative in South Asia) project, DAE are now promoting CA tillage technology. NGOs (RDRS, IDE, PROVA, CARITAS, farmers field school, farmer club) are also involved expanding these works in the farmers field.

Followings are the common CA based tillage equipments which are now using in the farmers field. 1. Minimum tillage seed drill 2. Strip tillage seed drill 3. Zero tillage seed drill and 4 . Raised bed planter.

\section{Minimum tillage seed drill}

The minimum tillage seed drill is operated by two

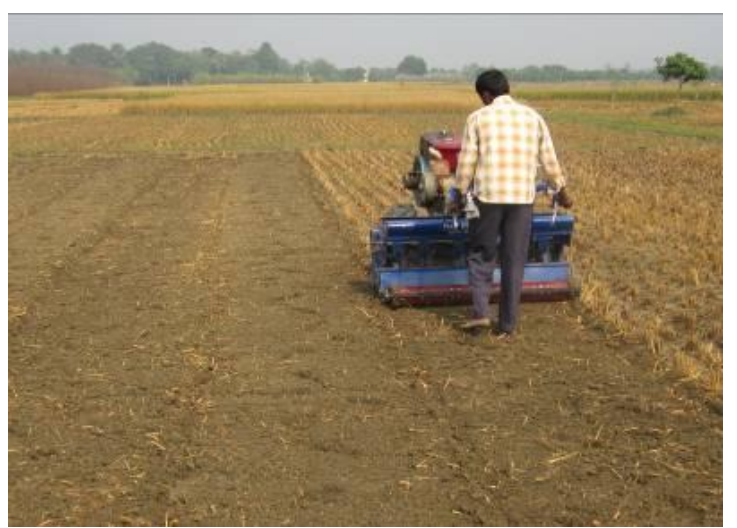

Fig. 1. Two wheel tractor operated seeder. wheel tractor $(9 \mathrm{~kW})$ and it is commonly known as power tiller operated seeder (PTOS) among the farming community. The seeding part of this drill needs to hitch with power tiller drawbar point through nuts and bolts replacing the tilling part. In the standard commercially available arrangement this seed drill is set up for one pass seeding with full rotary tillage. The seed box is set up above the tillage unit, and the seed delivered by tubes and lightweight soil openers to the 
soil immediately behind the tilled zone. A steel made long press roller then lightly firms the soil behind the seed drill. There is no fertilizer box in the original seeder unit. But, recently inclined plate seed meter was introduced and make a separate seed box with it. Now, seed and fertilizer can be applied with separate delivery tubes as per requirement. Improved furrow opener has been introduced which is capable placing seeds and fertilizer side by side, not in a mixing form. Before start seeding operation, mixed basal doses fertilizers are broadcasted over the soil surface. The minimum tillage seed drill comprises four operations - shallow tilling with high speed (450-500 rpm) of tilling blades, seeding in lines, seed covering with minimal press and land leveling (Fig.1). Most of the seeds (wheat, lentil, mungbean, maize, rice, chickpea, groundnut, jute) can be sown by the same seed drill with small changes such as for jute seeding mix rice husk with seed 4:1 proportion. The effective field capacity of the drill is $0.15 \mathrm{ha} / \mathrm{h}$ (Hossain et al., 2009a). Limitations of this technology are high price of the seeder and trained operator needed for effectively using the seeder.

\section{Strip tillage seed drill}

Strip tillage seed drill is one step ahead of minimum tillage seed drill in terms of soil disturbance and crop residue management. It is also operated by two wheel tractor and hitched similarly as a minimum tillage drill. Strip tillage seed drill performs as- strip tilling with high speed rotating blades, seed and fertilizer placed side by side and soil compaction over seeds with press wheel. The space between the tilled rows remains untilled. Fertilizer

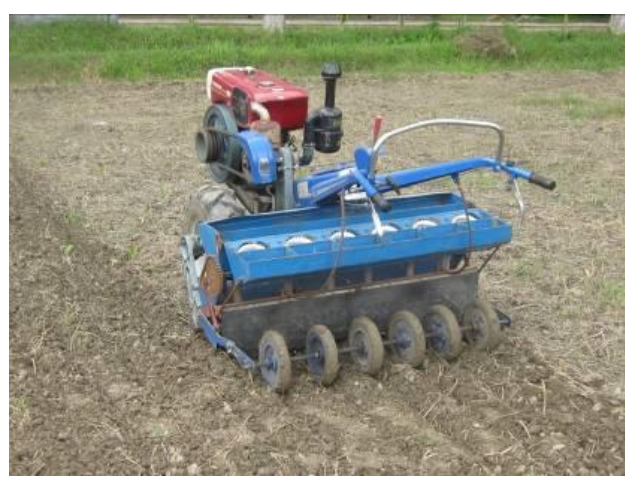

Fig. 2. Two wheel tractor operated strip till seeder

application is done by a separate operation, and fertilizer positioned besides the seed rows. Improved "T" type furrow opener has been introduced which is capable placing seeds and fertilizer side by side, not in a mixing form. The depth of seeding is adjustable according to the status of soil behavior and moisture condition.

Fig. 2 shows the rotary strip till drill. Strip till perform works through crop residue without plugging. Fot strip- tillage, generally four blades are used on the rotor shaft per line furrow making by the strip till equipment for minimizing the torque requirement and torque variation on the rotor shaft (Lee et al.,2003). The left bent and right bent blades are set facing towards the furrow centre. The average speeds of rotating blades are 400-450 rpm. 
The high speed rotation of the blades cut the previous crop residue and create the strip for seed and fertilizer placement. The average width of the furrow strip is 40-60 mm which is sufficient for placement of seed and fertilizers. The width of strip also depends on the specific requirement of the crops. Effective field capacity of the drill increased by $19 \%$ and fuel consumption reduced by $21 \%$ compared to traditional ploughing and manual broadcasting system (Hossain et al., 2012). Limitations of this technology are trained operator needed for effectively using the seeder. Recently operator's seat introduced with the strip till drill which facilitates long distance travel and more comfortably use.

\section{Zero till drill}

This is a pull type seeding implement and works as seeding and fertilizing at a time. Generally, granular type fertilizer like- Triple Super Phospate (TSP), DAP (Di Amonium Phosphate) are used in this system. This no till drill capable seeding operation through moderately dense (0.2$0.4 \mathrm{t} / \mathrm{ha}$ ) crop residue field. A set of press wheel was attached with toolbar frame for closing the seeding furrow. The planter was capable to apply

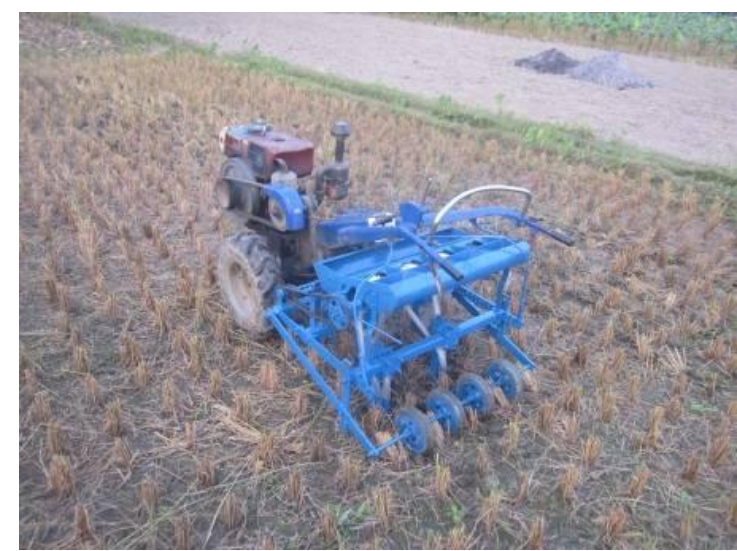

Fig. 3. Two wheel tractor operated zero till drill.

seed and fertilizer in a narrow $(30-35 \mathrm{~mm})$ opening slit at one operation. The planting depth and seed rate can be adjusted depending on crop standard. The inclined plate seed meter is used for metering seeds and flute type meter is used for metering fertilizers. The furrow opener of zero till drill is made with the used car leaf spring which is more strong, lighter in weight and more durable. Before seeding, round up herbicide applied for killing existing weeds. Fertilizer management and weed control was the key issue for adopting this new technology. Wheat, mungbean and maize were planted by the zero till drill in Rice-Wheat cropping system. Zero till wheat was less lodge compare to conventional planted wheat. The zero till drill can pull 4 tynes in soft and medium soil but 3 tynes for hard soil. Round up herbicide was applied to kill the weeds before seeding operation. Loose crop residue some times create problem but generally it does not happened in manually harvested fields. Zero-till farmers saved plant establishment cost $40-65 \%$ minimizing the average turn around time 9-10 days between the two crops. The effective field capacity of the no till drill was $0.15 \mathrm{ha} / \mathrm{h}$ (Hossain et al., 2009b). This drill enables farmers to sow seeds 
when soil moisture and optimum planting time is critical. This drill is structurally improved, lighter in weight and more versatile for different adjustment. Herbicide use and additional learning is more in this technology compare to conventional method.

\section{Raised bed planter}

Bed planter is a seeding implement which works as a formation of bed, fertilizing and seeding on the top of the bed at a time (Fig.4) maintaining the recommended agronomic practices. It is a pull type unit which attached with a power tiller replacing the rotary part of the tiller. The functional part of the bed planter are (i) toolbar frame (ii) furrow opener (iii) seed box with

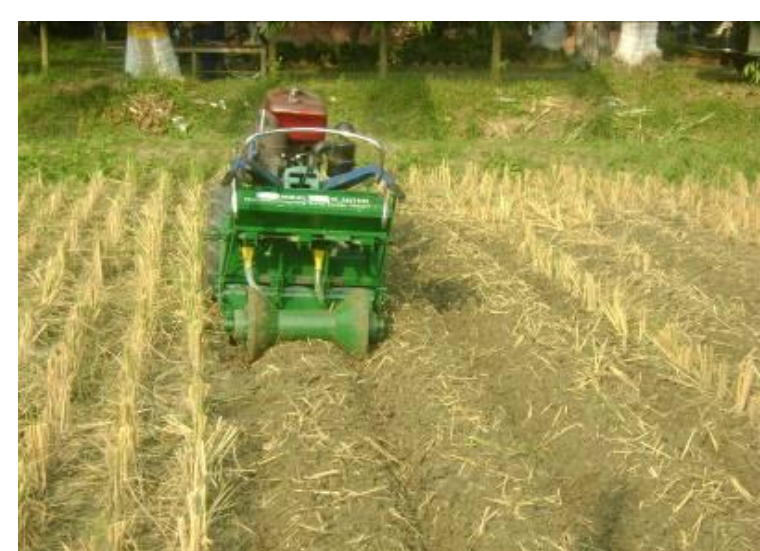

Fig. 4. Two wheel tractor operated bed planter. metering unit (iv) bed shaper (v) chain and sprocket for power transmission. It is required pre tilled soil for bed formation. Wheat, maize, mungeban, lentil, rice can be grown successfully on bed. Cornell University, Food for progress project (Hossain et al., 2014) finds out the following advantages- (i) Easy irrigation water application and less amount of water requirement (ii) Keeping bed permanent, crop grown without ploughing (iii) Higher yield compare to conventional system (iv) Minimum rat damage of crop (v) Easy intercultural operation. (vi) Less amount fertilizer requirement (vii) Less arsenic contamination in cereal gain.

The inclined plate seed meter is used for metering seeds and flute type meter is used for metering fertilizers. WRC and FMPE Division, BARI also developed rotary blade type bed planter which can form bed in untilled soil. It is also further improved introducing with fertilizer attachment and replacing seed metering mechanism. Bed planting systems are more popular in Rajshahi area. Farmers accept this technology and service providers started commercial business with this implement. Crop establishment difference between CA system and conventional system are shown in Table 1 . 
Table 1. Crop establishment differences between conservation agriculture system and conventional method.

\begin{tabular}{|c|c|c|c|}
\hline $\begin{array}{l}\text { S1 } \\
\text { No. }\end{array}$ & $\begin{array}{l}\text { Performance } \\
\text { parameter }\end{array}$ & CA tillage system & Conventional system \\
\hline 1 & Crop establishment & One pass direct seeding & $\begin{array}{l}\text { Land prepared by } 3-4 \\
\text { passes. Manual broadcasting }\end{array}$ \\
\hline 2 & Seed rate & Optimum & More than recommended \\
\hline 3 & Depth of planting & Uniform & Uneven \\
\hline 4 & Irrigation water & Less water & Comparatively more \\
\hline 5 & weeding & Comparatively easy & Difficult to control \\
\hline 6 & Fertilizer application & During seeding operation & $\begin{array}{l}\text { During land preparation and } \\
\text { top dress application }(2 / 3 \\
\text { split) }\end{array}$ \\
\hline 7 & Turn around time & Minimum & $\begin{array}{l}\text { 7-9 days required from first } \\
\text { ploughing to seeding }\end{array}$ \\
\hline
\end{tabular}

\section{Results and Discussion}

\section{Conservation agriculture based tillage works progress}

In Bangladesh, conservation agriculture based tillage technology was first introduced by CIMMYT-Bangladesh in the farmers field with wheat crops late 90's with minimum tillage technology by two wheel tractor (power tiller ) operated seeder (Amin et al., 2002). CIMMYT-Bangladesh also conducted limited number of strip tillage technology trials during that period through Wheat Research Centre, BARI in Northern Bangladesh. In the mean time, toolbar attached raised bed planter was developed in WRC- BARI (2002) and it was successfully demonstrated for wheat, maize, mungbean, and rice cultivation. Food and Agriculture Organization (FAO, Rawson et al., 2007) formed a two years project (2003-04) for intensification of wheat and wheat based cropping system through CA based tillage technology in four greater districts of Bangladesh (Dinajpur, Rajshahi, Jessore and Jamalpur) through WRC-BARI collaboration. Under FAO project two wheel tractor attached pull type zero till drill was first developed in WRC Dinajpur. CA promotional activities had been continuing in the farmers' field through FAO, CIMMYT supported activities. IRRI-ADB took over (2005-07) the CA works with direct seeding rice and wheat in Northern Bangladesh. Farmers start showing interest on CA technology considering the advantages of crops yield, cost and resources saves. Agricultural officials, researchers, extension personnel, machinery manufacturers are now involved in this system. ACIAR (2006-2009) 
implemented a project on legume crop sustainability in North-West part with a major component of tillage technology. Under this project, zero till drill, strip till drill has been much improved with a very acceptable limit by the farmers. Farm machinery Division, BARI further developed rotary type bed planter in 2006 with a single seed box. Considering the easiness of bed formation, WRCBARI -Cornell University (2010-14) Food for Progress project further improved the rotary type bed planter with the introduction of inclined plate seed meter, separate seed \& fertilizer box, split power transmission chain and set up operator's seat for easy movement and more adoption in the farmer's field of Rajshahi region and Faridpur areas. CSISA and CIMMYT are now expanding these tillage technology in Southern and central part of Bangladesh. ACIAR-SRFSI project is now actively involved for sustaining resilient farming through these tillage options in North-West part of Bangladesh. Moreover, leading NGOs like RDRS, IDE, CARITAS, PROVA are now expanding CA based technology in the farmers field. NARS (National Agricultural Research System) institutes especially BARI is now conducting various researches with many crops on the basis of CA technology. Agricultural universities in the country are now involved in CA based research and education.

The tillage implements are being used by the farmers and local service providers for different crop production. Numbers of tillage implements available in the country are shown in Table 2.

Table 2. Numbers of two wheel tractor based CA tillage implement.

\begin{tabular}{|c|c|c|c|}
\hline S1 No. & $\begin{array}{l}\text { Name of CA tillage } \\
\text { implement }\end{array}$ & Number & Remarks \\
\hline 1 & $\begin{array}{l}\text { Minimum tillage seed } \\
\text { drill }\end{array}$ & 865 & $\begin{array}{l}\text { Local made as well as } \\
\text { imported from China }\end{array}$ \\
\hline 2 & Strip tillage seed drill & 35 & $\begin{array}{l}\text { Local made as well as } \\
\text { imported from China }\end{array}$ \\
\hline 3 & Raised bed planter & 425 & Locally made \\
\hline 4 & Zero till drill & 8 & Locally made \\
\hline
\end{tabular}

Minimum tillage seed drill and raised bed planter are being used by the farmers and service providers as custom hire basis. Zero till drill and strip till drill are still using on farm demonstration basis with different crops by the research organizations under project works. Local manufacturers are gaining experiences producing quality CA machinery. Earlier seed metering devices are imported from China. Presently, these are making in local workshop with imported raw materials. 


\section{Adoption of minimum tillage and raised bed technology}

Considering the advantages and benefits of the minimum tillage seed drill, farmers are purchasing seeder (PTOS) for their own works as well as custom hiring system. Owners of PTOS in Dinajpur, Rajshahi, Faridpur districts are using for different seeds sowing commercially. It was observed that average 60 units of seeder increasing yearly (Fig.5). At present, there are 865 active numbers of seeders in operating condition.

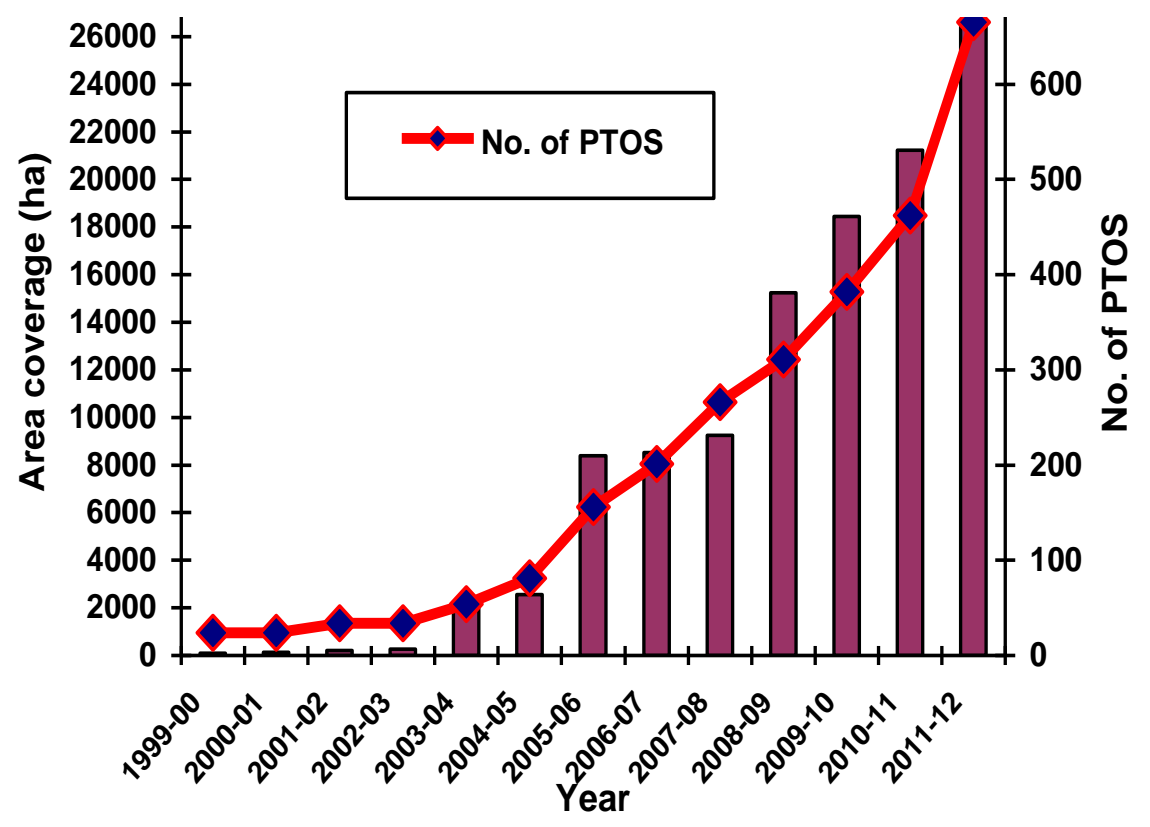

Fig.5. Adoption of minimum tillage

The adoption rate of minimum tillage technology in Faridpur area is much more than other other part of Bangladesh. The seeders are also engaged in onion field preparation in those area. Three local manufacturers started fabrication of seed this seed drill. Number of bed planters also increasing in Rajshahi area. Last year (2013-14), there are about 5764 ha area covered by bed planting technology for wheat, maize, mingbean, rice, vegetables cultivation. Total area under minimum tillage is 21850 ha. Area coverage under different tillage techniques are shown in Table 3. Minimum tillage and raised bed systems are becoming popular among the farmers and yearly area coverage is increasing. There are 20125 numbers of farmers involved in raised bed farming. 


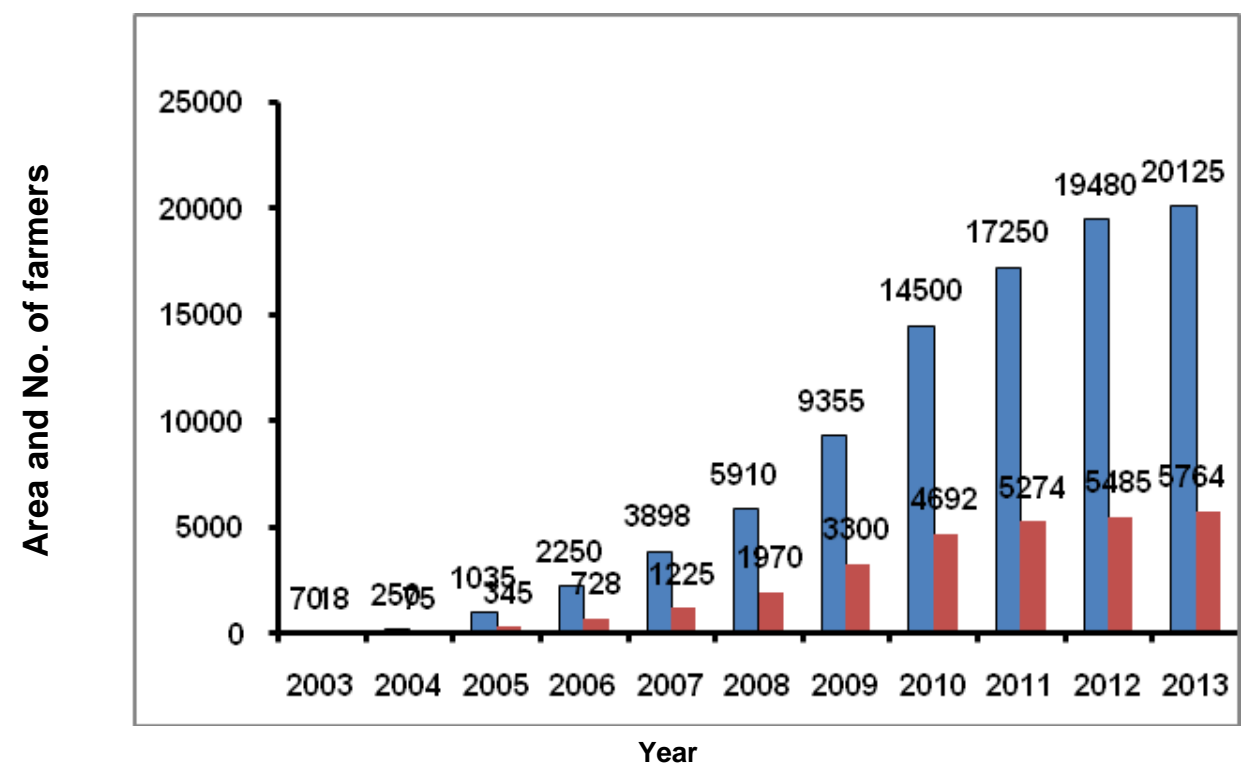

Fig 6 : Adoption of raised bed technology.

Table 3. Area coverage under conservation agriculture tillage system in Bangladesh.

\begin{tabular}{l|c|c|c}
\hline $\begin{array}{c}\text { Conservation agriculture Tillage } \\
\text { techniques }\end{array}$ & $\begin{array}{c}2010-11 \\
\text { (ha) }\end{array}$ & $\begin{array}{c}2011-12 \\
\text { (ha) }\end{array}$ & $\begin{array}{c}2012-13 \\
\text { (ha) }\end{array}$ \\
\hline Minimum tillage & 9864 & 17527 & 21850 \\
Strip tillage & 72 & 106 & 108 \\
Zero tillage & 79 & 59 & 97 \\
Raised bed system & 4337 & 4636 & 5745 \\
\hline Total & $\mathbf{1 4 3 5 2}$ & $\mathbf{2 2 3 2 8}$ & $\mathbf{2 7 8 0 0}$ \\
\hline
\end{tabular}

Uplands crops were best suited with CA tillage system. Yields of wheat, maize, pulses were significantly higher than conventional method (Table 4). Seeds and fertilizers can be applied optimum doses maintaining the standard practices. Research experiences revealed that yield of direct seeding rice was similar and some cases lower than conventional transplanting methods. Plant establishment was satisfactory but weed management or proper herbicide was not available. All the three years, it was observed that yield trend same as conservation agriculture tillage system reported higher yield over conventional methods. Farmers are gaining experiences in these new tillage systems for sustaining the crops yield. Crops yields on CA tillage system were much better than conventional system. 
Table 4. Yield comparison of major crops under CA tillage systems.

\begin{tabular}{|c|c|c|c|c|c|c|c|c|c|}
\hline \multirow{2}{*}{$\begin{array}{l}\text { Conservation } \\
\text { agriculture } \\
\text { tillage } \\
\text { system }\end{array}$} & \multicolumn{3}{|c|}{ 2010-11 (t/ha) } & \multicolumn{3}{|c|}{$2011-12(\mathrm{t} / \mathrm{ha})$} & \multicolumn{3}{|c|}{$\begin{array}{c}2012-13 \\
\text { (t/ha) }\end{array}$} \\
\hline & Wheat & maize & $\begin{array}{l}\text { Mung } \\
\text { bean }\end{array}$ & Wheat & maize & Mungbean & Wheat & maize & Mungbean \\
\hline $\begin{array}{l}\text { Minimum } \\
\text { tillage }\end{array}$ & $4.8 \mathrm{a}$ & 8.8 & $1.2 \mathrm{a}$ & $4.9 \mathrm{ab}$ & 8.8 & $1.2 \mathrm{a}$ & $4.7 \mathrm{a}$ & 9.5 & $1.3 \mathrm{a}$ \\
\hline Strip tillage & $5.1 \mathrm{a}$ & 8.6 & $1.0 \mathrm{~b}$ & $5.1 \mathrm{a}$ & 8.7 & $1.1 \mathrm{a}$ & $5.2 \mathrm{a}$ & 9.3 & $1.2 \mathrm{a}$ \\
\hline Zero till & $4.4 \mathrm{a}$ & 8.5 & $0.9 \mathrm{~b}$ & $4.3 \mathrm{bc}$ & 8.8 & $1.1 \mathrm{a}$ & $4.4 \mathrm{a}$ & 8.8 & $1.2 \mathrm{a}$ \\
\hline Bed planting & $4.8 \mathrm{a}$ & 8.8 & $0.95 \mathrm{~b}$ & $5.1 \mathrm{a}$ & 9.0 & $0.95 \mathrm{~b}$ & $5.2 \mathrm{a}$ & 9.7 & $1.0 \mathrm{~b}$ \\
\hline $\begin{array}{l}\text { Conventional } \\
\text { system }\end{array}$ & $3.5 \mathrm{~b}$ & 8.6 & $0.75 \mathrm{c}$ & $3.6 \mathrm{c}$ & 9.0 & $0.75 \mathrm{c}$ & $3.5 \mathrm{~b}$ & 9.0 & $0.7 \mathrm{c}$ \\
\hline $\begin{array}{l}\text { Level of } \\
\text { significance }\end{array}$ & 0.05 & NS & 0.01 & 0.01 & NS & 0.01 & 0.01 & NS & 0.01 \\
\hline $\mathrm{CV}(\%)$ & 9.54 & 8.63 & 7.29 & 8.49 & 9.51 & 7.03 & 9.40 & 8.38 & 6.53 \\
\hline $\operatorname{LSD}(0.05)$ & 0.81 & 1.41 & 0.13 & 0.74 & 1.59 & 0.13 & 0.81 & 1.46 & 0.13 \\
\hline
\end{tabular}

There were considerable costs saving in CA based tillage technologies (Table 5) over conventional methods. The cost saving by minimum tillage, strip tillage, zero tillage and bed planting system were $65 \%, 67.5 \%, 69 \%$ and $40 \%$, respectively than that of conventional methods of planting.

Table 5. Cost of planting in different $\mathrm{CA}$ tillage system over conventional methods.

\begin{tabular}{c|lc}
\hline Sl. No. & \multicolumn{1}{|c}{ CA tillage methods } & Cost of seeding (Tk./ha) \\
\hline 1 & Minimum tillage & $1950.0 \mathrm{c}$ \\
2 & Strip tillage & $1850.0 \mathrm{c}$ \\
3 & Zero tillage & $2175.0 \mathrm{c}$ \\
4 & Raised bed system & $3394.0 \mathrm{~b}$ \\
5 & Conventional method & $5695.0 \mathrm{a}$ \\
\hline & CV (\%) & 7.29 \\
& LSD (0.05) & 414 \\
\hline
\end{tabular}

$1 \mathrm{US} \$=\mathrm{Tk} .78 .0$

\section{Environment aspect}

CA based tillage machinery perform seeding operation with minimum disturbance of soil. Less amount of diesel fuel used in CA tillage system compare to conventional tillage method (Table 6). CA tillage system saved 94 1/ha/yr of costly diesel fuel and $44 \%$ less emission of $\mathrm{CO}_{2}$ into the atmosphere. This green 
house gas emission can be mitigated by shifting to direct seeded or zero tillage system.

Table 6. Comparative use of diesel fuel on conventional and reduced tillage method.

\begin{tabular}{l|c|c|c}
\hline \multicolumn{1}{c|}{ Tillage option } & Diesel used (1/ha/yr) & $\begin{array}{c}\mathrm{CO}_{2} \text { emission* } \\
(\mathrm{kg} / \mathrm{ha} / \mathrm{yr})\end{array}$ & $\begin{array}{c}\text { Fuel save } \\
(1 / \mathrm{ha} / \mathrm{yr})\end{array}$ \\
\hline Conservation agriculture system & 119 & 309.4 & 94 \\
Traditional method & 213 & 553.8 & 94 \\
\hline
\end{tabular}

Hossain et al., 2009a and *Grace et al., 2003.

\section{Constraints to CA tillage technology adoption}

Mind set up of high agricultural officials are not much favor convincing these CA tillage technologies. Limited investments of local manufacturers to scale-up production linked with uncertain CA machinery demand. The great numbers of resource poor smallholder farmers are not an attractive potential client group of machinery manufacturers. Manufacturing infrastructure and distribution channels of products are little developed. High price of machinery and low prices of agricultural produce discourage investments in agriculture, including machines and tools. Financial organizations are not much friendly to farmers in terms of reducing rate of interest and price installments. Absentee farmer and small landholder feel risk about crop failure with new technology. Additional learning is more comparing to conventional system. Research - extension-farmers linkage is not well established about these CA technologies transfer. Direct seeding rice is not yet in good shape in terms of weed management.

\section{Challenges in promotion of CA tillage technology}

Major challenges are to encourage private sector investment scaling up these technologies for the end users. Build up a mechanism for available appropriate CA implements and tools at an affordable price to farmers. Training needed for different level of workers, considering the advantages of conservation agriculture. Moreover, policy support is necessary for further acceleration of these technologies among the users.

\section{Conclusion}

Farmers accept conservation agriculture based tillage technologies considering the advantages of higher yields, reduced cost of tillage operation, and minimum turn around time between the crops. Up land crops are more suitable under these 
tillage technologies. Most of the tillage implements are operated by imported Chinese two wheel tractor (power tiller). There are few four wheel tractor CA implement. Minimum tillage seed drill, raised bed planter, zero till drill and strip till drills are being fabricated in different local machinery workshop. Some manufacturers can fabricate implements independently. There are considerable numbers of manufacturers fabricating tillage implement in different districts. Farmers started adopt the CA technologies, especially raised bed planting and minimum tillage technology. Weed management in rice cultivation is not yet in a good shape. Herbicide availability and proper using technique of those herbicides are still a problem. There are about 425 raised bed planters and 865 minimum tillage seed drills in the country. Area coverage under bed planting and minimum tillage system are 5764 ha and 21850 ha, respectively. There is a big prospect accelerating the CA based tillage technology in the farmers' field as irrigation water availability becoming limited or more costly. Mind set up is the big issue for adopting CA tillage technology. Training and multi disciplinary approaches can push forward these tillage technologies ahead.

Acknowledgements: The authors are pleased to acknowledge International Maize and Wheat Improvement Centre (CIMMYT), Cornell University-Food for progress (FFP) project in Bangladesh and Australian Centre for International Agriculture Research (ACIAR). The authors also extended their sincere thanks to Dr. Peter R Hobbs, Dr. Ken Sayre, Dr. Raj Gupta, Dr. Craig A Meisner, Dr.JK Ladha for their noble efforts for disseminating the CA technologies in South Asia as well as in Bangladesh.

\section{References}

Amin, M.R, A.M.A. Siddiquie, M. Bodruzzaman, P.K Malaker, M.A. Sufian, M.A Shahid, M.E Baksh, M. Ahmed, M.N Islam and M.A Reza. 2002. Assessing the long term implication of different tillage option for wheat in the rice -wheat system in Northern region of Bangladesh. DFID workshop held in Kathmandu, Nepal 7-10 May 2002 .

Barma, N.C.D., P.K. Malaker, Z.I Sarker, M.A. Khaleque, M. Israil Hossain, M.A.Z. Sarker, M. Bodruzzaman, M.A Hakim, and A. Hossain. 2014. Adoption of power tiller operated seeder in rice wheat cropping system. WRC, BARI Annual report, Nashipur, Dinajpur. Pp:248-253.

Bell, R. and C. Johansen. 2009. Annual report. Addressing constraints to pulses in cereals-based cropping systems, with particular reference to poverty alleviation in north-western Bangladesh. ACIAR (LWR/2005/001).

FAO CA web site: http://www.fao.org/ag/ca/1a.html.

Grace, P.R., M.C. Jain and L.W. Hamington.2003: Environmental concerns in Ricewheat systems. Proceedings of the international workshop on development of action 
program for farm level impact in rice-wheat system of the Indo-gangetic plains. 2527 Sep 2003.

Hobbs, P.R., K. Sayre, and R. Gupta. 2008. The role of conservation agriculture in sustainable agriculture. Philosophical Transactions of the Royal Society B: Biological Sciences 363 (1491):543-555

Israil Hossain, M.I Hossain, M.N.A. Siddiqui, G.M Panaullah, J.M. Duxbury and J.G. Lauren. 2014. Raised beds: A resource conserving technology for improved crop production in Bangladesh. A booklet under Cornell University-Food for progress programme in Bangladesh.

Hossain, M.I., M.S. Islam, C.A. Meisner, M.Bodruzzaman and Ilias Hossain.2009a. Minimum tillage one pass seeder for sustaining cropping intensity and profitability in rice-wheat system. Int. J. Sustain. agril. Tech. 5(6):32-37

Hossain, M.I., R.J.Esdaile, R. Bell, E.Haque and C. Johansen.2009b. Development of a low cost two wheel tractor operated no-till seeder for better establishment of upland crop. Eco-friendly Agril. J. 2(11):915-919

Hossain, M.I, Ilias Hossain, M.A.A Mamun, N.A Siddique, M. Mahabubur Rahman and M. Sq Rahman. 2012. Two wheel tractor operated strip tillage seeding equipment for dry land farming. International Journal of Energy Machinery 5 (1):35-41

Lee, K.S., S.H. Park, W.Y. Park and C.S. Lee. 2003. Strip tillage characteristics of rotary tiller blades for use in a dry land direct rice seeder. Soil and Tillage Research. Vol.71 (1): $25-32$

Roy K.C, M.E. Haque, Scott Kustice, Israil Hossain and C.A. Meisner.2009. Development of tillage machinery for conservation agriculture in Bangladesh. AMA, 40 (2):58-64

Rawson,H.M.; H.Gomez-Macpherson; A.B.S.Hossain; Saifuzzaman;H.Rashid; M.A.Sufian; M.A.Samad; A.Z.Sarker; F.Ahmed; Z.I.Talukder; MoznurRahman; M.M.A.B. Siddique; I.Hossain and M.Amin. 2007. On-farm wheat trials in Bangladesh: A study to reduce perceived constraints to yield in traditional wheat areas and Southern lands that remain fallow during the dry season. Expl.Agric. 43:21-40

Satter Mondal, M.A. 2013. Workshop of the Agricultural engineering technology development and dissemination. FMP Engineering Division, of BARI, Gazipur, 5 June 2013. 